\title{
PRAKTIK KECURANGAN AKUNTANSI DALAM PERUSAHAAN
}

\author{
Yuniarti Hidayah Suyoso Putra \\ Akutansi Fakultas Ekonomi UIN Maulana Malik Ibrahim Malang \\ Jln. Gajayana 50 Malang \\ HP. 081334119895 \\ e-mail: yuniarti_hidayah@yahoo.com \\ HP. 081334119895
}

\begin{abstract}
This paper describes accounting fraud in company. Previous researches indicate several factors driven accounting fraud such as opportunity, exposure, individual aspect, poor internal control, and ineffective employee's placement and management model. Recurrence of accounting fraud is happened either because of well planned and perpetrators are forced to do it. However, diverse methods can be conducted to detect and prevent accounting fraud and is supported by high moral commitment and law enforcement.
\end{abstract}

Key Words: Kecurangan akuntansi, pendeteksian dan pencegahan.

WorldCom, perusahaan telekomunikasi terbesar kedua di Amerika Serikat, mengakui telah melakukan skandal akuntansi yang menyebabkan perdagangan sahamnya di bursa NASDAQ terhenti. Beberapa minggu kemudian, WorldCom menyatakan diri bangkrut. Perusahaan telah memberi gambaran yang salah tentang kinerja perusahaan dengan cara memalsukan milyaran bisnis rutin sebagai belanja modal, sehingga labanya overstated sebesar \$11 milyar pada awal 2002. Perusahaan juga meminjamkan uang lebih dari \$400 juta kepada Chief Executive Officer (CEO)nya waktu, Bernard Ebbers, untuk menutupi kerugian perdagangan pribadinya. Ironisnya meski di dakwa telah melakukan pemalsuan, konspirasi dan laporan keuangan yang salah, mantan CEO WorldCom tersebut mengaku tidak bersalah (Mehta, 2003; Klayman, 2004; Reuters, 2004).

Enron Corp., perusahaan terbesar ke tujuh di AS yang bergerak di bidang industri energ, para manajernya memanipulasi angka yang menjadi dasar untuk memperoleh kompensasi moneter yang besar. Praktik kecurangan yang dilakukan 
antara lain yaitu di Divisi Pelayanan Energi, para eksekutif melebih-lebihkan nilai kontrak yang dihasilkan dari estimasi internal. Pada proyek perdagangan luar negerinya misal di India dan Brasil, para eksekutif membukukan laba yang mencurigakan. Strategi yang salah, investasi yang buruk dan pengendalian keuangan yang lemah menimbulkan ketimpangan neraca yang sangat besar dan harga saham yang dilebih-lebihkan. Akibatnya ribuan orang kehilangan pekerjaan dan kerugian pasar milyaran dollar pada nilai pasar (Schwartz, 2001; Mclean, 2001). Kasus ini diperparah dengan praktik akuntansi yang meragukan dan tidak independennya audit yang dilakukan oleh Kantor Akuntan Publik (KAP) Arthur Andersen terhadap Enron. Arthur Anderson, yang sebelumnya merupakan salah satu "The big six" tidak hanya melakukan memanipulasi laporan keuangan Enron tetapi juga telah melakukan tindakan yang tidak etis dengan menghancurkan dokumen-dokumen penting yang berkaitan dengan kasus Enron. Independensi sebagai auditor terpengaruh dengan banyaknya mantan pejabat dan senior KAP Arthur Andersen yang bekerja dalam department akuntansi Enron Corp. Baik Enron maupun Anderson, dua raksasa industri di bidangnya, sama-sama kolaps dan menorehkan sejarah kelam dalam praktik akuntansi.

Indonesia, kasus skandal akuntansi bukanlah hal yang baru. Salah satu kasus yang ramai diberitakan adalah keterlibatan $10 \mathrm{KAP}$ di Indonesia dalam praktik kecurangan keuangan. KAP-KAP tersebut ditunjuk untuk mengaudit 37 bank sebelum terjadinya krisis keuangan pada tahun 1997. Hasil audit mengungkapkan bahwa laporan keuangan bank-bank tersebut sehat. Saat krisis menerpa Indonesia, bank-bank tersebut kolaps karena kinerja keuangannya sangat buruk. Ternyata baru terungkap dalam investigasi yang dilakukan pemerintah bahwa KAP-KAP tersebut terlibat dalam praktik kecurangan akuntansi. $10 \mathrm{KAP}$ yang dituduh melakukan praktik kecurangan akuntansi adalah Hans Tuanakotta and Mustofa (Deloitte Touche Tohmatsu's affiliate), Johan Malonda and Partners (NEXIA International's affiliate), Hendrawinata and Partners (Grant Thornton International's affiliate), Prasetyo Utomo and Partners (Arthur Andersen's affiliate), RB Tanubrata and Partners, Salaki and Salaki, Andi Iskandar and Partners, Hadi Sutanto (menyatakan tidak bersalah), S. Darmawan and Partners, Robert Yogi and Partners. Pemerintah 
pada waktu itu hanya melakukan teguran tetapin tidak ada sanksi. Satu-satunya badan yang berhak untuk menjatuhkan sanksi adalah BP2AP (Badan Peradilan Profesi Akuntan Publik) yaitu lembaga non pemerintah yang dibentuk oleh Ikatan Akuntan Indonesa (IAI). Setelah melalui investigasi BP2AP menjatuhkan sanksi terhadap KAP-KAP tersebut, akan tetapi sanksi yang dijatuhkan terlalu ringan yaitu BP2AP hanya melarang 3 KAP melakukan audit terhadap klien dari bank-bank, sementara 7 KAP yang lain bebas (Suryana, 2002).

Kasus-kasus tersebut menggambarkan bagaimana para akuntan nakal telah melanggar prinsip dasar etika profesi, terutama integritas, objektivitas, dan perilaku profesional. Permasalahan utama adalah mengapa praktik kecurangan akuntansi tersebut terus berulang, apakah ada indikasi tindakan kecurangan yang terjadi adalah tindakan yang terencana ataukah memang para akuntan terpaksa melakukannya, siapa saja yang berpotensi melakukan kecurangan akuntansi di perusahaan, dan jika fakta menunjukkan bahwa kecurangan akuntansi terus berulang lalu bagaimana cara perusahaan mendeteksi dan mencegahnya?

\section{PRAKTIK KECURANGAN AKUNTANSI}

Praktek kecurangan akuntansi bisa timbul dalam berbagai bentuk. Simanjuntak (2008) mengklasifikasikan fraud (kecurangan) menjadi 4 golongan berdasarkan pencatatan, frekuensi, konsiprasi dan keunikan.

\section{Berdasarkan Pencatatan}

Kecurangan berupa pencurian aset dapat dikelompokkan kedalam tiga kategori, yaitu:

a. Pencurian aset yang tampak secara terbuka pada buku, seperti duplikasi pembayaran yang tercantum pada catatan akuntansi (fraud open onthebooks), kecurangan jenis ini lebih mudah untuk ditemukan

b. Pencurian aset yang tampak pada buku, namun tersembunyi diantara catatan akuntansi yang valid, seperti: kickback (fraud hidden on the-books)

c. Pencurian aset yang tidak tampak pada buku, dan tidak akan dapat dideteksi melalui pengujian transaksi akuntansi "yang dibukukan", seperti: pencurian 
uang pembayaran piutang dagang yang telah dihapusbukukan/di-write-off (fraud off-the books), kecurangan jenis ini paling sulit untuk ditemukan.

\section{Berdasarkan Frekuensi}

Pengklasifikasian kecurangan berdasarkan frekuensi terjadinya, yaitu:

a. Tidak berulang (non-repeating fraud).

Kecurangan yang tidak berulang, walaupun terjadi beberapa kali, pada dasarnya bersifat tunggal. Misalnya kecurangan dalam pembayaran cek mingguan karyawan, maka pelaku memerlukan kartu kerja mingguan untuk melakukan pembayaran cek yang tidak benar.

b. Berulang (repeating fraud)

kecurangan berulang, tindakan yang menyimpang terjadi beberapa kali dan hanya diinisiasi/diawali sekali saja, selanjutnya kecurangan terjadi terusmenerus sampai dihentikan. Misalnya cek pembayaran gaji bulanan yang dihasilkan secara otomatis tanpa harus melakukan penginputan setiap saat. Penerbitan cek terus berlangsung sampai diberikan perintah untuk menghentikannya.

\section{Berdasarkan Konspirasi}

Kecurangan yang terjadi karena adanya konspirasi bona fide maupun pseudo. Bona fide conspiracy, yaitu semua pihak sadar akan adanya kecurangan, sedangkan pseudo conspiracy, ada pihak-pihak yang tidak mengetahui terjadinya kecurangan.

\section{Berdasarkan Keunikan}

Kecurangan berdasarkan keunikannya dapat dikelompokkan sebagai berikut:

a. Kecurangan khusus (specialized fraud),

Terjadi secara unik pada orang-orang yang bekerja pada operasi bisnis tertentu. Contoh:

(1) Pengambilan aset yang disimpan deposan pada lembaga-lembaga keuangan, seperti bank, dana pensiun, reksa dana. Kecurangan jenis disebut juga dengan custodial fraud

(2) Klaim asuransi yang tidak benar.

b. Kecurangan umum (garden varieties of fraud) 
Mungkin hadapi oleh semua orang dalam operasi bisnis secara umum. Misalnya kickback yaitu penetapan harga yang tidak benar, pesanan pembelian/kontrak yang lebih tinggi dari kebutuhan yang sebenarnya, pembuatan kontrak ulang atas pekerjaan yang telah selesai, pembayaran ganda, dan pengiriman barang yang tidak benar.

The ACFE (The Association of Certified Fraud Examiners), Asosiasi Pemeriksa Kecurangan Bersertifikat yang berkedudukan di Amerika Serikat, menggolongkan kecurangan dalam 3 (tiga) jenis atau tipologi berdasarkan perbuatan yaitu:

\section{Penyimpangan atas Asset (Asset Misappropriation)}

Penyalahgunaan/pencurian aset atau harta perusahaan atau pihak lain. Ini merupakan bentuk fraud yang paling mudah dideteksi karena sifatnya yang tangible atau dapat diukur/dihitung (defined value).

\section{Pernyataan Palsu atau Salah Pernyataan (Fraudulent Statement)}

Tindakan yang dilakukan oleh pejabat atau eksekutif suatu perusahaan atau instansi pemerintah untuk menutupi kondisi keuangan yang sebenarnya dengan melakukan rekayasa keuangan (financial engineering) dalam penyajian laporan keuangannya untuk memperoleh keuntungan atau mungkin dapat dianalogikan dengan istilah window dressing.

\section{Korupsi (Corruption)}

Jenis fraud ini yang paling sulit dideteksi karena menyangkut kerja sama dengan pihak lain seperti suap dan korupsi. Fraud jenis ini yang terbanyak terjadi di negara-negara berkembang yang penegakan hukumnya lemah dan masih kurang kesadaran akan tata kelola yang baik sehingga faktor integritasnya masih dipertanyakan. Korupsi sering kali tidak dapat dideteksi karena para pihak yang bekerja sama menikmati keuntungan. Termasuk didalamnya adalah penyalahgunaan wewenang/konflik kepentingan (conflict of interest), penyuapan (bribery), penerimaan yang tidak sah/illegal (illegal gratuities), dan pemerasan secara ekonomi (economic extortion). 
Penjabaran dari ketiga golongan kecurangan Uniform Occupational Fraud Classification System menurut ACFE dapat dilihat pada gambar 1.

Gambar 1. Bagan Uniform Occupational Fraud Classification System menurut ACFE

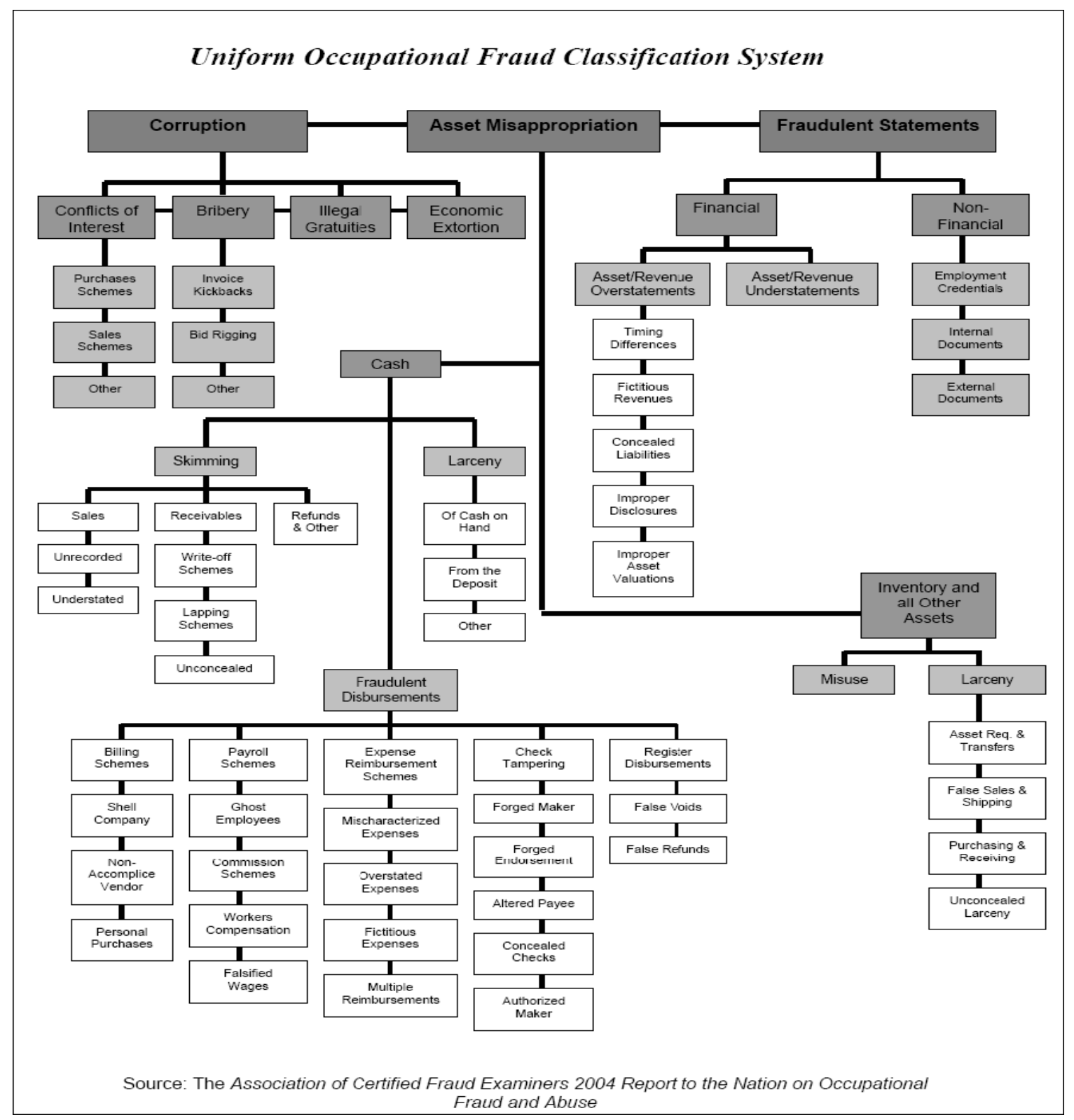

\section{KEJADIAN DAN TERUS BERULANG}

Beberapa faktor menjadi pendorong mengapa kecurangan akuntansi terus berulang diuraikan berikut. Simanjuntak (2008) menyoroti faktor yang mendorong seseorang melakukan kecurangan bisa berasal dari faktor generik dan individu yaitu: 


\section{Faktor Generik / Umum}

Merupakan faktor yang berhubungan dengan organisasi sebagai korban perbuatan kecurangan. Faktor ini meliputi:

a. Kesempatan (Opportunity)

Kesempatan untuk melakukan kecurangan tergantung pada kedudukan pelaku terhadap objek kecurangan. Umumnya, manajemen suatu organisasi atau perusahaan memiliki potensi yang lebih besar untuk melakukan kecurangan daripada karyawan. Tetapi patut digaris bawahi bahwa kesempatan untuk melakukan kecurangan selalu ada pada setiap kedudukan.

b. Pengungkapan (Exposure)

Terungkapnya suatu kecurangan dalam organisasi atau perusahaan belum menjamin tidak terulangnya kecurangan tersebut baik oleh pelaku yang sama maupun oleh pelaku yang lain. Oleh karena itu, setiap pelaku kecurangan seharusnya dikenakan sanksi apabila perbuatannya terungkap.

\section{Faktor Individu}

Faktor yang berhubungan dengan individu sebagai pelaku kecurangan. Faktor ini terdiri dari:

a. Ketamakan (Greed)

Ketamakan berhubungan dengan moral individu. Pandangan hidup dan lingkungan berperan dalam pembentukan moral seseorang.

b. Kebutuhan (Need)

Berhubungan dengan pandangan/pikiran dan keperluan pegawai/pejabat yang terkait dengan aset yang dimiliki perusahaan/instansi/organisasi tempat ia bekerja. Selain itu tekanan (pressure) yang dihadapi dalam bekerja dapat menyebabkan orang yang jujur mempunyai motif untuk melakukan kecurangan. 
Amrizal (2004) menggaris bawahi bahwa pada dasarnya praktik kecurangan akuntansi akan terus berulang dalam suatu entitas jika:

1. Pengendalian intern tidak ada atau lemah atau dilakukan dengan longgar dan tidak efektif.

2. Pegawai dipekerjakan tanpa memikirkan kejujuran dan integritas mereka.

3. Pegawai diatur, dieksploitasi dengan tidak baik, disalahgunakan atau ditempatkan dengan tekanan yang besar untuk mencapai sasaran dan tujuan keuangan yang mengarah tindakan kecurangan.

4. Model manajemen sendiri melakukan kecurangan, tidak efsien dan atau tidak efektif serta tidak taat terhadap hukum dan peraturan yang berlaku.

5. Pegawai yang dipercaya memiliki masalah pribadi yang tidak dapat dipecahkan biasanya masalah keuangan, kebutuhan kesehatan keluarga, gaya hidup yang berlebihan.

6. Industri dimana perusahaan menjadi bagiannya, memiliki sejarah atau tradisi kecurangan.

\section{ANTARA MOTIF TERENCANA DAN KETERPAKSAAN}

Faktor pendorong yang telah dijelaskan pada pembahasan sebelumnya menjadi dasar mengapa seseorang melakukan kecurangan. Faktor pendorong itu pulalah yang menyebabkan seseorang dapat melakukan perencanaan untuk melakukan kecurangan. Seperti yang terjadi pada kasus Enron Corp., iming-iming insentif moneter yang cukup besar, memicu para eksekutifnya untuk melakukan manajemen laba untuk meraih insentif yang besar. Kesempatan yang ada dan rendahnya pengendalian internal serta tidak independennya akuntan dari Arthur Anderson menyebabkan kecurangan itu mudah itu terjadi.

Kecurangan akuntansi bisa juga terjadi bila ada suatu keterpaksaan, misalnya ketergantungan terhadap klien. Misalnya proporsi total pendapatan Kantor Akuntan Publik milik auditor itu sebagian besar berasal dari satu perusahaan atau kelompok perusahaan (Sabeni, 2006). Atau bisa disebabkan karena tekanan-tekanan dari pihak manajemen yang menyebabkan akuntan tidak bisa berkutik. Pada saat hal tersebut terjadi maka independensi dari para akuntan akan benar-benar diuji. 
Banyak kasus kecurangan, khususnya kasus pencurian dan penggelapan aset, biasanya terdapat tiga faktor yang mendasari yaitu ada satu tekanan pada seseorang, seperti kebutuhan keuangan, adanya kesempatan untuk melakukan kecurangan dan menyembunyikan kecurangan yang dilakukan, adanya cara pembenaran perilaku tersebut yang sesuai dengan tingkatan integritas pelakunya (Amrizal, 2004).

\section{PELAKU KECURANGAN AKUNTANSI}

Pelaku kecurangan akuntansi bisa berasal dari internal maupun eksternal perusahaan.

\section{Internal Perusahaan}

\section{a. Karyawan}

Karyawan melakukan kecurangan bertujuan untuk keuntungan individu, misalnya salah saji yang berupa penyalahgunaan aktiva

\section{b. Manajemen}

Pihak manajemen melakukan kecurangan biasanya untuk kepentingan perusahaan, yaitu salah saji yang timbul karena kecurangan pelaporan keuangan. Namun tidak menutup kemungkinan, manajemen melakukan kecurangan hanya untuk kepentingan pribadi. Seperti pada kasus Enron, para eksekutifnya memberikan laporan keuangan yang salah dengan melebih-lebihnya labanya guna meraih kompensasi moneter yang besar dari perusahaan.

\section{Eksternal Perusahaan}

Pihak ekternal yang berpotensi melakukan kecurangan jika tidak memegang teguh kode etik profesi antara lain auditor, akuntan publik. Konflik kepentingan selalu ada, misalnya tidak independennya auditor maupun akuntan pada kasus Enron. Pihak lain yang berpotensi terjadi kecurangan bisa berasal dari pelanggan, distributor maupun supplier perusahaan. 


\section{CARA MENDETEKSI DAN MENCEGAH PRAKTIK KECURANGAN AKUNTANSI}

\section{PENDETEKSIAN}

Pendeteksian terjadinya praktik kecurangan bisa dilakukan dengan mengenali gejala-gejalanya antara lain:

\section{Gejala Kecurangan pada Manajemen}

Umumnya agak sulit dideteksi, namun gejalanya dapat dikenali yaitu timbulnya ketidakcocokan diantara manajemen puncak, rendahnya moral dan motivasi karyawan, Departemen akuntansi kekurangan staf, tingkat komplain yang tinggi terhadap organisasi/perusahaan dari pihak konsumen, pemasok, atau badan otoritas, terjadi kekurangan kas secara tidak teratur dan tidak terantisipasi, menurunnya tingkat penjualan atau laba sementara utang dan piutang usaha meningkat, perusahaan mengambil kredit sampai batas maksimal untuk jangka waktu yang lama, terdapat kelebihan persediaan yang signifikan, terdapat peningkatan jumlah ayat jurnal penyesuaian pada akhir tahun buku.

\section{Gejala Kecurangan pada Karyawan/Pegawai}

Gejala kecurangan yang dilakukan oleh karyawan atau pegawai dapat dikenali antara lain yaitu pembuatan ayat jurnal penyesuaian tanpa otorisasi manajemen dan tanpa perincian/penjelasan pendukung, melakukan pengeluaran tanpa dokumen pendukung, pencatatan yang salah/tidak akurat pada buku jurnal/besar, penghancuran, penghilangan, pengrusakan dokumen pendukung pembayaran, kekurangan barang yang diterima, kemahalan harga barang yang dibeli, munculnya faktur ganda, penggantian mutu barang (Sie Infokum, 2008).

Perubahan perilaku drastis dari individu yang melakukan kecurangan bisa digunakan sebagai indikasi (Sie Infokum, 2008), antara lain yaitu

1. Perubahan perilaku secara signifikan, seperti: easy going, tidak seperti biasanya, gaya hidup mewah, mobil atau pakaian mahal

2. Gaya hidup di atas rata-rata

3. Sedang mengalami trauma emosional di rumah atau tempat verja 
4. Penjudi berat

5. Peminum berat

6. Sedang dililit utang

7. Temuan audit atas kekeliruan (error) atau ketidakberesan (irregularities) dianggap tidak material ketika ditemukan

8. Bekerja tenang, bekerja keras, bekerja melampaui jam kerja, sering bekerja sendiri.

Amrizal (2004) menguraikan garis besar cara mendeteksi kecurangan menurut $A C F E$ adalah sebagai berikut:

1. Kecurangan Laporan Keuangan (Financial Statement Fraud).

Kecurangan dalam penyajian laporan keuangan umumnya dapat dideteksi melalui analisis laporan keuangan sebagai berikut:

a. Analisis vertikal, yaitu teknik yang digunakan untuk menganalisis hubungan antara item-item dalam laporan laba rugi, neraca, atau Laporan arus kas dengan menggambarkannya dalam persentase.

b. Analisis horizontal, yaitu teknik untuk menganalisis persentase-persentase perubahan item laporan keuangan selama beberapa periode laporan.

c. Analisis rasio, yaitu alat untuk mengukur hubungan antara nilai-nilai item dalam laporan keuangan Sebagai contoh adalah current ratio, adanya penggelapan uang atau pencurian kas dapat menyebabkan turunnya perhitungan rasio tersebut

\section{Penyalahgunaan Aset (Asset Misappropriation)}

Variasi pendeteksian kecurangan jenis ini sangat beragam. Pemahaman terhadap pengendalian intern atas pos-pos tersebut akan sangat membantu dalam mendeteksi kecurangan. Metode-metode yang bisa digunakan antara lain:

a. Analiytical Review

Review atas berbagai akun yang mungkin menunjukkan ketidak biasaan atau kegiatan-kegiatan yang tidak diharapkan.

b. Stastitical Sampling 
Melakukan sampling atas pos-pos tertentu yang dicurigai, misalnya persediaan. Dokumen dasar pembelian dapat diuji secara sampling untuk menentukan ketidakbiasaan (irregularities), metode deteksi ini akan efektif jika ada kecurigaan terhadap satu attributnya, misalnya pemasok fiktif. Suatu daftar alamat PO BOX akan mengungkapkan adanya pemasok fiktif

c. Vendor or outsider Complaints

Komplain / keluhan dari konsumen, pemasok, atau pihak lain merupakan alat deteksi yang baik yang dapat mengarahkan auditor untuk melakukan pemeriksaan lebih lanjut.

d. Site Visite - Observation

Observasi ke lokasi biasanya dapat mengungkapkan ada tidaknya pengendalian intern di lokasi-lokasi tersebut.

\section{Korupsi (Corruption)}

Kecurangan ini dapat dideteksi melalui keluhan dari rekan kerja yang jujur, laporan dari rekan, atau pemasok yang tidak puas dan menyampaikan komplain ke perusahaan. Atas sangkaan terjadinya kecurangan ini kemudian dilakukan analisis terhadap tersangka atau transaksinya.

\section{PENCEGAHAN}

Pencegahan terjadinya praktik kecurangan akuntansi dapat dilakukan dengan beberapa cara. Wilopo (2006) dalam penelitiannya mengemukakan bahwa upaya menghilangkan perilaku tidak etis manajemen dan kecenderungan kecurangan akuntansi dapat dilakukan antara lain dengan:

a. Mengefektifkan pengendalian internal, termasuk penegakan hukum

b. Perbaikan sistem pengawasan dan pengendalian

c. Pelaksanaan good governance

d. Memperbaiki moral dari pengelola perusahaan, yang diwujudkan dengan mengembangkan sikap komitmen terhadap perusahaan, negara dan masyarakat. 


\section{KESIMPULAN}

Praktik kecurangan akuntansi dalam perusahaan hanya bisa dicegah dan dibasmi apabila ada komitmen tinggi untuk tidak melakukan berbagai bentuk kecurangan dari masing-masing individu pelaku, manajemen maupun pihak lain yang terlibat. Krisis moral pada saat ini memang menjadi masalah utama dan berbagai cara memang bisa ditempuh untuk mendeteksi dan mencegah kecurangan termasuk dengan mengefektifkan pengendalian internal, penegakan hukum, melaksanakan good governance, tetapi jika moral tidak berubah dan sikap komitmen yang tinggi terhadap pemberantasan segala praktik kecurangan tidak terlaksana maka semua langkah pemberantasan yang ditempuh tidak akan berguna.

Ke depan penelitian dan publikasi terkait dengan praktik-praktik kecurangan yang terjadi sangat perlu terus dilakukan dengan metode yang tepat termasuk metode-metode dalam mendeteksi dan mencegah kecurangan, sehingga mampu memberikan informasi yang adil dan dapat dipertanggungjawabkan kepada masyarakat luas, menunjukkan komitmen yang tinggi dari para akademisi maupun praktisi, yang pada akhirnya dapat mendorong pemerintah melakukan penegakan hukum yang adil sehingga memberikan efek jera kepada pelaku kecurangan. 


\section{DAFTAR PUSTAKA}

Arens, A.A., Randal J. Elder., dan Mark S. Beasly (2008). Auditing dan Jasa Assurance Pendekatan Integrasi. Edisi Ke-12. Penerbit Erlangga. Jakarta.

Institut Akuntan Publik Indonesia (2008). Standar Profesional Akuntan Publik-Kode Etik Profesi Akuntan Publik.

Klayman, B. (2004). MCI Reduces Earnings by \$74,4 Billion. Reuters.com, 12 Maret 2004.

Koroy, T. R. (2008). Pendeteksian Kecurangan (Fraud) Laporan Keuangan oleh Auditor Eksternal. Jurnal Akuntansi dan Keuangan, Vol. 10, No. 1, Mei 2008: 22-33

McLean, B. (2001). Why Enron Went Bust. Fortune, 9 Desember 2001.

Mehta, S.N. (2003). Is MCI Being Good Enough? Fortune, 24 Oktober 2003.

Reuters (2004). WorldCom Chief Turns Himself In to FBI. Reuters.com, 3 Maret 2004

Sabeni, A. (2006). Auditor Nakal: Kesengajaan atau Keterpaksaan? Suara Merdeka. www.suaramerdeka.com/harian/0608/12/eko08.htm, 12 Agustus 2006.

Schwartz, N.D. (2001). Enron Fallout: Wide But Not Deep. Fortune, 9 December 2001.

Sie Infokum (2009). Fraud (Kecurangan): Apa dan Mengapa? Ditama Binbangkum. Diunduh dari www.jdih.bpk.go.id/informasihukum/Fraud(kecurangan).pdf, 28 Agustus 2009.

Simanjuntak, R. (2008). Kecurangan: Pengertian dan Pencegahan. Diunduh dari www.asei.co.id/internal/docs/Asei-Kecurangan.doc, 14 Oktober 2008.

Suryana, A. (2002). Indonesia is no stranger to accounting scams: Expert. The Jakarta Post. Thursday, 11 Juli 2002.

Wilopo (2006). Analisis Faktor-faktor yang Berpengaruh Terhadap Kecenderungan Kecurangan Akuntansi : Studi pada Perusahaan Publik dan Badan Usaha Milik Negara di Indonesia. Simposium Nasional Akuntansi (SNA) 9. Padang, 23 - 26 Agustus 2006. 